\title{
Personality Disorder in Convicted Jamaican Murderers
}

\author{
FW Hickling ${ }^{1}$, G Walcott ${ }^{2}$
}

\begin{abstract}
Objective: To establish the aetiology and historical prevalance of personality disorder in violent homicidal men in Jamaica.

Methods: Examination and analysis of primary data from the psychosocial case study interviews of 36 convicted murderers from the Jamaican Government Barnett Commission of Enquiry in 1976. The disaggregated social and clinical data were analysed using a Chi-square statistical analysis

Results: The mean age at time of arrest for the male convicted murderers was $24.26 \pm 8.48$ years. Twenty-three (66\%) of the subjects had loving relationships with mothers, particularly in those men reared in the rural areas. Twenty-one (59\%) cases showed marked paternal rejection and absence of integrated family life. Twenty-four (69\%) of the cases experienced severe parental disciplinary methods, and two-thirds were illiterate or barely literate. Twenty-nine (83\%) were from very poor socio-economic conditions. Thirty (86\%) of all the murder victims were adult males. There were significant differences between the urban reared murderers (URM) and rural reared murderers (RRM). Sixteen (94\%) of the victims of the URM ensued from robbery and police confrontation, while 13 (72\%) of the victims of the RRM resulted from domestic disputes $(\mathrm{p}<0.00)$. Seventeen $(49 \%)$ of the men had normal personalities; 18 (51\%) were diagnosed as having antisocial and inadequate personalities. Diagnosis of primary data using Diagnostic and Statistical Manual of Mental Disorders fourth edition, text revision (DSM-IV-TR) criteria revealed 23 (66\%) men with Antisocial Personality Disorder (APD). There were significantly more APD in the URM than the RRM $(p<0.01)$.

Conclusions: Antisocial personality disorder as an aetiological precursor of homicidal violence represents a major public health problem in contemporary Jamaica.
\end{abstract}

Keywords: Antisocial personality disorder, convicted murderers, Jamaica public health

\section{Trastornos de Personalidad en Asesinos Jamaicanos Convictos}

\author{
FW Hickling ${ }^{1}, \mathrm{G}$ Walcott $^{2}$
}

\begin{abstract}
RESUMEN
Objetivo: Establecer la etiología y la prevalencia histórica de los trastornos de personalidad en hombres violentos homicidas en Jamaica.

Métodos: Examen y análisis de los datos principales de las entrevistas de casos de estudio psicosociales de 36 asesinos convictos, tomadas de la Comisión de Investigación Barnett del Gobierno de Jamaica en 1976. Los datos clínicos y sociales desagregados se analizaron mediante un análisis estadístico chicuadrado.

Resultados: La edad promedio al momento del arresto de los asesinos convictos fue $24.26 \pm 8.48$ años. Veintitrés (66\%) de los sujetos tenían relaciones afectuosas con las madres, especialmente aquellos hombres criados en las zonas rurales. Veintiún casos (59\%) mostraron un marcado rechazo paternal y ausencia de vida familiar integrada. Veinticuatro (69\%) de los casos experimentaron severos métodos disciplinarios por parte de los padres, y dos tercios eran analfabetos o apenas sabian leer y escribir. Veintinueve (83\%) tenían muy malas condiciones socio-económicas. Treinta (86\%) de todas las víctimas de los asesinatos eran varones adultos. Hubo diferencias significativas entre los asesinos
\end{abstract}

From: ${ }^{1}$ Caribbean Institute of Mental Health and Substance Abuse (CARIMENSA), Faculty of Medical Sciences, The University of the West Indies, Kingston 7, Jamaica, West Indies and ${ }^{2}$ South East Regional Health Authority, Kingston and St Andrew Public Health Service, 1 Marescaux, Road Kingston 5, Jamaica, West Indies.
Correspondence: Professor FW Hickling, Caribbean Institute of Mental Health and Substance Abuse (CARIMENSA), Faculty of Medical Sciences, The University of the West Indies, Kingston 7, Jamaica,West Indies. E-mail: frederick.hickling@uwimona.edu.jm; fred@fredhickling.com 
criados en áreas urbanas (abreviado en inglés, URM) y los asesinos criados en áreas rurales (en inglés, RRM). Dieciséis (94\%) de las víctimas de los asesinos provenientes de zonas urbanas (URM) fueron consecuencia de robos y confrontación con la policía, mientras que 13 (72\%) de las víctimas de los asesinos de zonas rurales (RRM) fueron resultado de disputas domésticas $(\mathrm{p}<0.00)$. Diecisiete $(49 \%)$ de los hombres tenían personalidades normales; 18 (51\%) fueron diagnosticados con personalidad antisocial e inadecuada. El diagnóstico a partir de datos primarios mediante criterios de DSM-IV-TR reveló 23 hombres (66\%) con Trastorno de Personalidad Antisocial (TPA). Hubo significativamente más TPA entre los URM que entre los RRM ( $p<0.01)$.

Conclusiones: El trastorno de personalidad antisocial como precursor etiológico de la violencia homicida representa un problema importante de salud pública en la Jamaica actual.

Palabras claves: Trastorno de personalidad antisocial, asesinos convictos, salud pública de Jamaica

West Indian Med J 2013; 62 (5): 454

\section{INTRODUCTION}

There have been no published studies of personality disorder in Jamaican men convicted for murder, and few published studies of the prevalence of personality disorder in Jamaica. Although the Barnett Commission Report (1) on 36 convicted murderers at the St Catherine District Prison in Jamaica was published in 1976, there has been no publication of the results of the psychiatric clinical evaluation of these men. Jamaica, with a homicide rate of 53/100 000 in 2011, has the third highest rate of lethal violence in the world after El Salvador and Iraq (2). In view of the paucity of historical data available on the study of personality disorder in Jamaica, this study presents a review of the psychosociological findings from the Barnett Commission Report with the hypothesis of the existence of a high prevalence of personality disorder in men convicted of violent murder in Jamaica nearly forty years ago.

\section{SUBJECTS AND METHOD}

This is an analysis of primary data culled from the findings of the Barnett Commission of Enquiry 1976 which included a report of a psychosociological investigation of the 36 convicted murderers who had attempted to break out of prison in 1974. The team consisted of two consultant psychiatrists Drs Frederick W Hickling and Frank Knight, a consultant psychologist Dr Ruth Doorbar, and two social workers/probation officers $\mathrm{Mr} \mathrm{Hu}$ Marsh and Mr Earle Fearon who investigated the social circumstances and conditions of each man and made summaries of the official record of the murder trial of each man. Each psychiatrist interviewed each prisoner separately. The psychologist conducted the following psychometric tests: the Weschler Adult Intelligence Scale, the Thematic Apperception Test (TAT), the House/Three Person Test (HTP) and the Rorschach Test (RT). The social workers took complete social histories from each man, investigated all possible criminal, probation and approved school record and paid home visits to the relatives of each prisoner in an attempt to provide an accurate picture of their lives and early development. The data were disaggregated and collated and subjected to Chi-square statistical analysis. The case histories of the convicted men were re-evaluated by the present authors using Diagnostic and Stastical Manual of Mental Disorders, fourth edition, text revision (DSM-IV-TR) criteria for antisocial personality disorder.

Criterion A: There is a pervasive pattern of disregard for and violation of the rights of others occurring since age 15 years, as indicated by three (or more) of the following:

(i) failure to conform to social norms with respect to lawful behaviours as indicated by repeatedly performing acts that are grounds for arrest, (ii) deceitfulness, as indicated by repeated lying, use of aliases, or conning others for personal profit or pleasure, (iii) impulsivity or failure to plan ahead, (iv) irritability and aggressiveness, as indicated by repeated physical fights or assaults, (v) reckless disregard for safety of self or others, (vi) consistent irresponsibility, as indicated by repeated failure to sustain consistent work behaviour or honour financial obligations, (vii) lack of remorse, as indicated by being indifferent to or rationalizing having hurt, mistreated, or stolen from another.

Criterion B: The individual is at least age 18 years.

Criterion $\mathrm{C}$ : There is evidence of conduct disorder with onset before age 15 years.

Criterion D: The occurrence of antisocial behaviour is not exclusively during the course of schizophrenia or a manic episode.

\section{RESULTS}

A half of the convicted men (18) were reared in the rural areas of Jamaica, and the other half (18) were reared almost exclusively in urban innercity garrison communities of Kingston. One man from the Kingston reared group who was suffering from a severe psychotic illness was removed from the analysis because his responses were so disintegrated that it was impossible to gather any meaningful data from him. The mean age at time of arrest of the convicted murderers was $24.26 \pm 8.48$ years with $24(66 \%)$ below age 25 years. 
Fathers: Paternity was admitted by fathers of $33(94 \%)$ of the convicted men. In $17(49 \%)$ cases, the father had never lived with the mother at any time. Most fathers $(21,59 \%)$ had showed little or no interest in their sons' upbringing, and $20(56 \%)$ had not cohabitated meaningfully with their sons' mother. Thirty-three (94\%) fathers of the prisoners had 1-3 other families beside that of the subject and his mother.

Mothers: The majority of the subjects $(22,63 \%)$ lived for most of their formative life with their mothers and had long relationships with them. Eight (22\%) of the mothers of the subjects had one other baby father (besides subject's father), 13 (37\%) had two other baby fathers, eight $(23 \%)$ had three other baby fathers, four (11\%) had four other baby fathers and one had five other baby fathers.

Parental surrogates: Of the 35 men, nine (28\%) were strongly influenced by maternal surrogates in their upbringing, $12(34 \%)$ were influenced by paternal surrogates, and five $(14 \%)$ were reared by both maternal and paternal surrogates. This means that $26(74 \%)$ of this group of men were reared, at least in part, by people who were not their natural parents.

Parental discipline: Twenty-four (69\%) of the men had experienced flogging as punishment producing wales on the skin or cuts and bruises to the body, with $14(40 \%)$ of these being flogged frequently.

Schooling and literacy: Twenty-four $(69 \%)$ of the men had reached between grades 0 and 4 in school and $11(31 \%)$ had reached grade 5 or more. Of these latter, five (14\%) had reached grade 8 , and one (3\%) had reached grade 9 . Only 13 $(37 \%)$ attained a fair degree of literacy at school. Eleven $(31 \%)$ were semi-literate and $11(31 \%)$ were totally illiterate.

Employment: Six of the 35 men $(17 \%)$ had started working for a living by age 10 . Ten of the men $(29 \%)$ had started working before they were age 14, and 16 men (46\%) had started working between ages 14 and 15 years.

Rural $v s$ urban reared men: There was a fundamental dichotomy in the social and developmental data which separated and distinguished the rural reared men (RRM) from those urban reared men (URM) from innercity Kingston garrisons (Table 1). Rural reared men had less paternal rejection and warmer maternal relationships than URM. The punishments that they received as children were less frequent and less severe that the URM. Rural reared men were more poorly educated and had poorer levels of literacy but had a more stable record of employment.

Murder victims: Thirty (86\%) of all the murder victims were adult males. The URM, with their lack of stable cohabitation patterns, were found to have killed $100 \%$ adult males. In many instances, the motive was robbery; in others it was a physical fight growing out of conflict and confrontation. Of the RRM, five (22\%) had murdered adult women, four $(16 \%)$ had murdered a wife or paramour and 16 $(88 \%)$ had either an intimate or casual knowledge of the victim. By contrast, 14 (80\%) of the URM never knew or had any previous knowledge of their victims.

Types of weapons: Guns were used in $13(77 \%)$ of the crimes committed by URM but in only two (11\%) of the crimes committed by RRM. Rurally reared men tended more to utilize knives or machetes $(16,89 \%)$ in their acts of murder.

Intelligence: The overall functioning of the URM exceeded that of the RRM. The mean functioning IQ for the URM was 97, and the average functioning IQ for the RRM was 77. The mean IQ for intellectual endowment was 86 for the RRM and 106 for the URM, with two of the subjects in the latter group having intellectual endowments in the superior range $(120-130)$ and one in the very superior range

Personality: Of the total population assessed, 17 (49\%) were described as having a normal personality. Of the remaining, $11(31 \%)$ were assessed as having antisocial personalities, six $(17 \%)$ were diagnosed with inadequate personalities and one (3\%) was diagnosed with paranoid personality. More RRM, 13 (37\%), than urban men, four $(11 \%)$, were diagnosed as having normal personalities,

Table 1: Comparative history: rural vs urban reared convicted murderers in Jamaica

\begin{tabular}{lcccc}
\hline Rural vs urban convicted murderers & Chi- & Df & $p$ & Significance \\
& square & & & sig \\
\hline Greater financial support from father & 3.75 & 1 & $<0.05$ & v sig \\
Less beating with belt in childhood & 15.1 & 1 & $<0.00$ & sig \\
Less severity of beating in childhood & 3.75 & 1 & $<0.05$ & sig \\
Lower grade level of school attainment & 5.93 & 1 & $<0.01$ & sig \\
Lower literacy level at graduation & 9.12 & 1 & $<0.01$ & sig \\
More unskilled occupation status & 5.90 & 1 & $<0.01$ & sig \\
Greater employment stability record & 6.56 & 1 & $<0.01$ & sig \\
Lower minimum level of earnings & 8.58 & 1 & $<0.01$ & sig \\
Lower maximum level of earnings & 10.3 & 1 & $<0.01$ & sig \\
More female murder victims & 5.51 & 1 & $<0.02$ & v sig \\
Greater domestic conflict than robbery and rebellion & 17.2 & 1 & $<0.00$ & v sig \\
Greater intimate or casual knowledge of victim & 24.8 & 1 & $<0.00$ & v sig \\
Mainly knives and machetes vs guns as murder weapon & 15.3 & 1 & $<0.00$ & sig \\
More normal personalities & 10.2 & 3 & $<0.02$ & sig \\
Much fewer DSM-IV-TR antisocial personality disorders & 7.44 & 1 & $<0.01$ & \\
\hline
\end{tabular}


whereas more URM $(9,26 \%)$ were diagnosed with antisocial personality compared with RRM $(2,6 \%)[$ Chi-square $=8.30$, $1 \mathrm{df}, p<0.01]$.

Personality disorders: Using the DSM-IV-TR criteria for antisocial personality disorder on the evidence culled from their recorded case histories, Criteria B and D were scored as positive for all the 35 men studied. Criteria A and C were graded for all of the convicted murderers (Table 2).

\section{DISCUSSION}

Despite advances in economic, political and social development within the region, crime and structural and interpersonal violence continue to increase in the Jamaican society, with a current homicide rate of 53/100 000, the third highest in the world after El Salvador and Iraq (2). The rate of 2.9/100 000 of self-inflicted violence, or suicide (3) is ranking amongst one of the lowest in the world. Is violence a

Table 2: DSM-IV-TR diagnosis of antisocial personality/disorder culled from recorded case histories

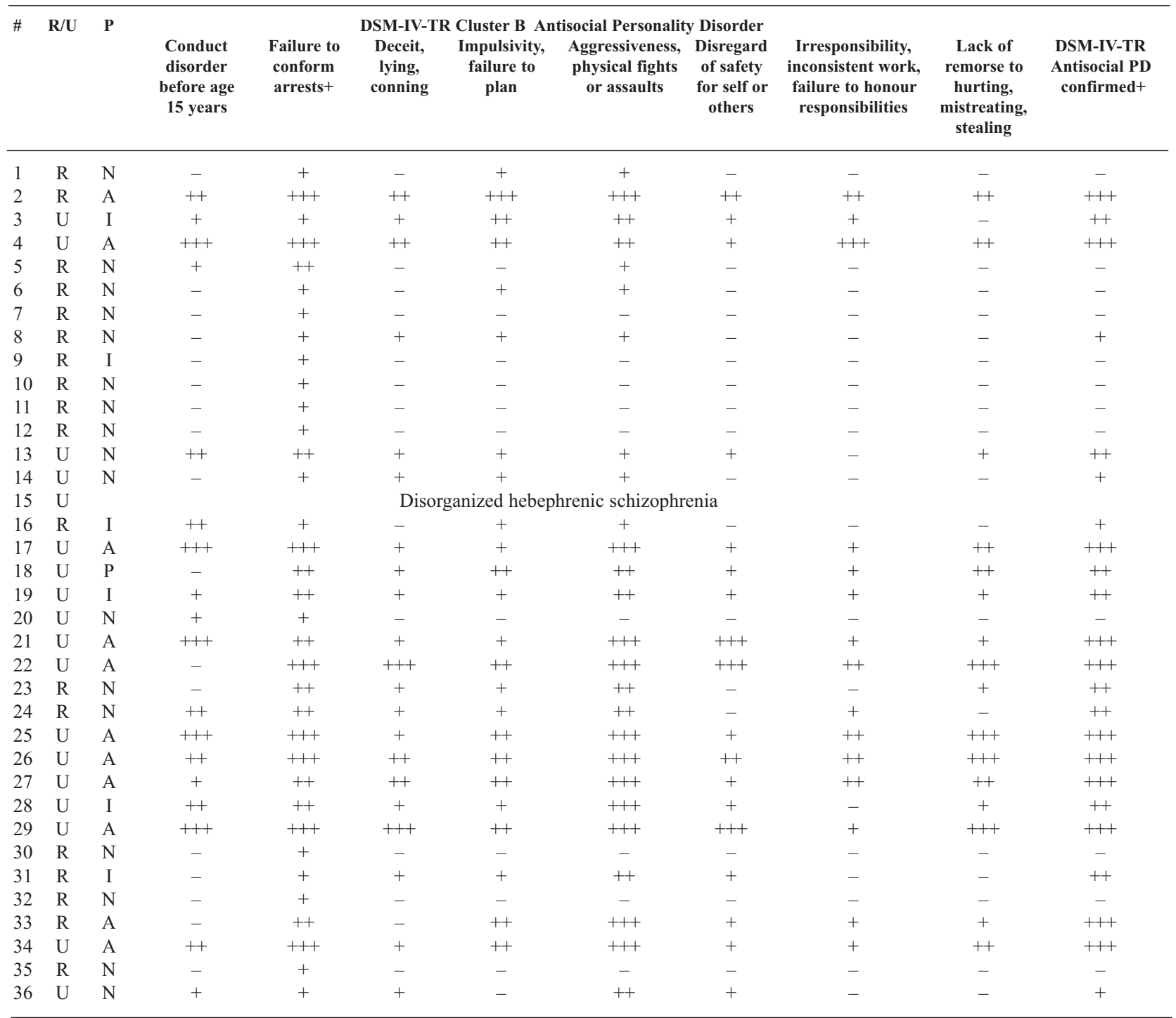

$\#$ = case history number; $\mathrm{R} / \mathrm{U}=$ rural/urban; $\mathrm{P}=$ personality;

$\mathrm{N}=$ normal personality; $\mathrm{A}=$ antisocial personality; $\mathrm{I}=$ inadequate personality; $\mathrm{P}$ = paranoid personality

Diagnostic and Statistical Manual of Mental Disorders, fourth edition, text revision (DSM-IV-TR) diagnosis of antisocial personality disorder

$($ ASPD) confirmed: $(-)$ normal $=12(34.3 \%) ;(+)$ mild ASPD $=4(11.4 \%) ;(++)$ moderate ASPD = $8(22.9 \%) ;(+++)$ severe ASPD $=11(31.4 \%)$

Of these, $23(66 \%)$ were diagnosed as having antisocial personality disorders, including five men who had been assessed by the initial Barnett Enquiry clinical team as having normal personalities. There were significantly more URM $(15,43 \%)$ who had DSM-IV-TR antisocial personality disorder than $\operatorname{RRM}(8,21 \%)[$ Chi-square $=7.44, \mathrm{df}=1, p<0.01]$. mental health problem? This study suggests that homicide is a significant public mental health problem in Jamaica. The control of intentional violence is usually left to the criminal justice system, while war and group conflict are the domain of psychiatrists, anthropologists and political scientists (4). Caribbean society seems extremely tolerant and even 
accommodating of violence in its various forms, and the subject has become the concern of diverse disciplines, including criminology, psychology, psychiatry, social work, sociology, child development, public health, and law and justice (5).

The legacy of slavery and the brutal plantation life imposed by colonial rule are seen as major contributors to the protracted violence experienced in the Caribbean. Hickling (6) argues that violence, originally manifested as rebellion against political, economic and racial exploitation, was turned inward as tribalism and self-destruction, following the development of Universal Adult Suffrage under the Westminster system of parliamentary democracy in the decade of the 1940s. Most instances of lethal violence in Jamaica occur in the innercity garrison communities of Kingston metropolitan area $(7,8)$. Figueroa and Sives (9) describe the development of the garrison community in Jamaica as a unique postcolonial feature of the Jamaican political system. George Beckford (10) in his writings described postcolonial plantation economies as having systematic suppression of opportunities for the majority to ensure the maintenance of a large unskilled labour force for the privileged few. It has therefore been suggested that the social and economic inequality and close proximity of both high-income earners and the very poor are to be blamed for the violence $(11,12)$. The terrorism associated with the garrison process breeds a deep fear of armed enforcers and its potential for lethal violence.

The primary data from the psychosociological study that accompanied the Barnett Report of 1976 commissioned by then Prime Minister Michael Manley has provided us with a unique opportunity to take a snapshot of the inner workings of the violence that has errupted in Jamaica in the past fifty years of independence from British colonial rule, and that has erupted from the innercity garrison communities of Kingston. This present study has indicated that two-thirds of the cohort of 35 men convicted for murder in Jamaica in 1974 had a DSM-IV-TR diagnosis of antisocial personality disorder. There was a fundamental dichotomy in the cohort data which separates and distinguished those men reared in rural surroundings from those men reared in the innercity garrisons of Kingston. There were statistically significantly fewer antisocial personality disorders in the 18 rurally reared men than the 17 predominantly innercity garrison reared men. Most of the convicted murderers showed evidence of early paternal rejection and revealed much conscious and unconscious anger and repressed hostility toward this rejection, and expressed resentment and blame at their father's desertion. Those reared in Kingston were shown to have received beatings with belt, strap or more severe punishments to a much greater extent than those reared in the rural areas. We suggest that this may have played an important part in accen- tuation of aggressive drives in the urban men, and a greater degree of resentful rebelliousness against authority figures. This study has revealed rural/urban differences in areas of poor socio-economic background, psychosocial patterns of behaviour, delinquency and criminal records, characteristics of capital crime (method, weapon, victim), intelligence and patterns of personality disorder. The RRM may be seen as persons who may have committed murders related to poor emotional control toward situations in which they saw a single person (usually known to them) who threatened their personal welfare. The URM on the other hand, represent persons who, by virtue of their psychological background and experiences, are committed to acts and behaviour which take the form of rebellion and attacks against the establishment.

\section{CONCLUSION}

The poverty in rural and urban Jamaica and the dynamics of innercity garrison communities in our society stand indicted as major causes of personality disorder and insane homicidal violence in this country, and represents a major public health problem in contemporary Jamaica.

\section{REFERENCES}

1. Barnett L. Report of a commission of enquiry into the attempted outbreak from the St Catherine district prison, Jamaica, on December 26, 1974. Jamaica government report; 1976.

2. Krause K, Muggah R, Gilgen E. Global burden of armed violence. Cambridge: Cambridge University Press; 2011.

3. Abel WD, Bourne PA, Hamil HK, Thompson EM, Martin JS, Gibson $\mathrm{RC}$ et al. "A public health and suicide risk in Jamaica from 2002 to 2006". North Am J Med Sci 2009; 1: 142-7.

4. Pedersen D. "Political violence, ethnic conflict and contemporary wars: broad implications for health and social well-being". Soc Sci Med 2002; 55: 175-90.

5. Matthies B, Meeks-Gardner J, Daley A, Crawford-Brown C. Issues of violence in the Caribbean. In: Hickling FW, Matthies BM, Morgan KA, Gibson RC, eds. Perspectives in Caribbean Psychology. Kingston: CARIMENSA Press, The University of the West Indies; 2008.

6. Hickling FW. Violence in Jamaica. Caribbean Journal of Religious Studies 1994; 15: 3-13.

7. Harriott A, Brathwaite F, Wortley S. Crime and criminal justice in the Caribbean. Kingston, Jamaica: Arawak Publications; 2004.

8. Lemard G, Hemenway D. Violence in Jamaica: an analysis of homicides 1998-2002. Inj Prev 2006; 12: 15-8.

9. Figueroa M, Sives A. Homogenous voting, electoral manipulation and the 'garrison' process in post-independence Jamaica. Commonwealth and Comparative Politics 2002; 40: 81-108.

10. Beckford G. Persistent poverty: underdevelopment in plantation economies of the third world. New York: Oxford University Press; 1972.

11. Headley BD. The Jamaican crime scene: a perspective. Mandeville, Jamaica: Eureka Press Limited; 1994.

12. Robotham, D. "The notorious riot": the socio-economic and political base of Paul Bogle's revolt. Kingston, Jamaica: Institute of Social and Economic Research; 1984. 